\title{
Risikofaktorer ved nyretransplantasjon
}

\begin{abstract}
Tid i dialyse og tidlig akutt rejeksjon er risikofaktorer for dårlig pasient-
\end{abstract} overlevelse etter nyretransplantasjon hos pasienter over 70 år. Det viser en norsk studie.

Registerstudien omfattet 354 pasienter over 70 år transplantert ved Rikshospitalet i perioden 1990-2005 (1). Utstrakt bruk av levende giver ved nyretransplantasjon har gjort at vi i Norge har hatt relativt korte ventelister. Dette er også en grunnene til at man aldri har hatt noen fast øvre aldersgrense for nyretransplantasjon. Pasienten må gjennomgå og bestå en standardutredning.

Rikshospitalet er Europas største transplantasjonssenter, og Norsk nefrologiregister har verdens største database på eldre nyretransplanterte pasienter fra ett sykehus. Disse dataene er nå analysert med tanke på å påvise eventuelle risikofaktorer som kan predikere redusert pasient- eller transplantatoverlevelse.

Pasientene hadde en median alder ved transplantasjonstidspunktet på 73,5 år. Median overlevelse etter transplantasjon var 5,3 år. Akutt rejeksjon de første tre månedene etter transplantasjonen ga $75 \%$ økt

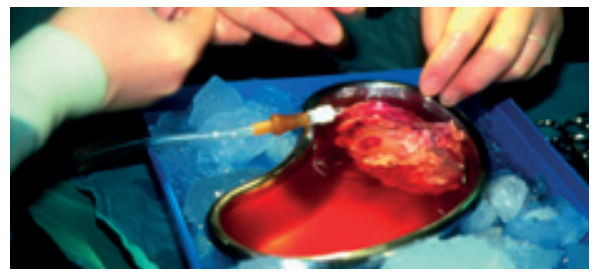

Illustrasjonsfoto Science Photo Library/GV-Press/ NordicPhotos

risiko for død, mens hver måned med dialysebehandling før transplantasjon økte risikoen med $2 \%$.

Det er viktig å unngå tidlig akutt avstøtning, og tid i dialyse før transplantasjon bør reduseres til et minimum for å få optimalt resultat ved nyretransplantasjon hos eldre.

\section{Kristian Heldal}

kristian.heldal@sthf.no

Seksjon for nyre/hormon

Medisinsk avdeling

Sykehuset Telemark

\section{Litteratur}

Heldal K, Hartmann H, Leivestad T et al. Clinical outcomes in elderly kidney transplant recipient are related to acute rejection episodes rather than pre-transplant comorbidity. Transplantation 2009; 87: $1045-51$.

\section{Nye løsninger ved nyretransplantasjon}

\section{Nyretransplantasjoner fra frivillige donorer til fremmede mottakere kan redusere ventetiden på friske nyrer. Men i Norge er forholdene små, og ventelistene heldigvis korte.}

Alternativet til å stå på venteliste for nyretransplantasjon er å ha et familiemedlem som donor. Hvis potensiell donor ikke er blodgruppeforlikelig, har man i noen land et system der donor og mottaker kobles sammen med et annet par i samme situasjon. Operasjonene må skje samtidig, fordi det ellers hender at den ene donoren trekker seg etter at den første transplantasjonen er ferdig.

En artikkel i The New England Journal of Medicine beskriver et alternativ til slike parede løsninger: En altruistisk donor, dvs. en levende donor som vederlagsfritt gir fra seg et organ til en fremmed, starter en kjede (1). Mottakerens «donorpartner» gir sitt organ til en annen pasient, hvis partner gir sin nyre til en tredje osv. Løsningen sikrer at ingen blir uten donor dersom én trekker seg. I dette tilfellet klarte man å gjennomføre en slik donorkjede med hele ti vellykkede transplantasjoner.

- I Norge bruker vi ikke bytte av giver på denne måten, sier seksjonsoverlege Per
Pfeffer ved Transplantasjonskirurgisk seksjon, Rikshospitalet. Hvis noen skal gi et organ til et menneske utenom familien, skal de være ukjente for hverandre. Det er nesten umulig $i$ et land med bare ett transplantasjonssenter. Vi bruker heller ikke altruistiske donorer. Man må være veldig sikker på at en person frivillig vil la seg operere for å gi til en ukjent, og det er verken ønskelig eller juridisk mulig å kunne hindre en donor i når som helst å kunne trekke seg fra operasjonen.

Norge har kortere ventelister enn USA og de aller fleste land. På grunn av en økende andel eldre $\mathrm{i}$ befolkningen og flere med livsstilssykdommer, vil behovet for nyretransplantasjon øke. Vi kan nå fjerne blodgruppeantistoffer og gjennomføre transplantasjoner der det tidligere var umulig. Vi har gode erfaringer med denne løsningen og unngår de mer kompliserte regimene, sier Pfeffer.

\section{Ragnhild Ørstavik \\ ragnhild.orstavik@fhi.no \\ Tidsskriftet}

\section{Litteratur}

Rees MA, Kopke JE, Pelletier RP et al. A nonsimultaneous, extended, altruistic-donor chain. N Engl J Med 2009; 360: 1096-101.

\section{Mindre kjøtt, bedre helse}

Høyt inntak av rødt og bearbeidet kjøtt er forbundet med økt dødelighet. En slik sammenheng er kjent fra mindre studier, men er nå for første gang vist i en stor, populasjonsbasert prospektiv undersøkelse, der man hadde mulighet for å kontrollere for en lang rekke andre forhold (Arch Intern Med 2009; 169: 562-71). Basert på utregninger fra de omtrent 500000 deltakerne fant forskerne at en reduksjon i inntak av rødt kjøtt tilsvarende den kvintilen med lavest forbruk ville redusere dødeligheten av hjerte- og karsykdommer med $11 \%$ hos menn og $21 \%$ hos kvinner.

Kjøtt og kjøttproduksjon affiserer ikke bare den enkeltes helse direkte. I en lederartikkel i samme nummer (s. 543-5) beskriver Barry Popkin, amerikansk økonom og leder av et tverrfaglig senter for overvekt ved Chapel Hill-universitetet i North Carolina, hvordan etterspørselen etter kjøtt påvirker verdens matvaresituasjon, vannforsyninger og klima.

\section{Brunt fett}

Brunt fettvev har helt andre oppgaver enn det vanlige hvite: Hos spedbarn og gnagere fører aktivering av det brune fettvevet til $ø$ øt energiforbruk og høyere kroppstemperatur og bidrar til at kjernetemperaturen opprettholdes. Hos voksne mennesker har man imidlertid regnet med at brunt fettvev har liten eller ingen funksjon. Men resultatene fra tre studier publisert i The New England Journal of Medicine 12009; 360 : 1500-8, 1509-17, 1518-25) viser at dette sannsynligvis ikke stemmer: Slikt fettvev fanges opp ved positronemisjonstomografi (PET-skanning) og utgjør en viktig feilkilde når man søker etter malignt vev.

Resultatene fra de tre studiene, som alle er basert på PET-skanninger, viser at brunt fettvev også finnes hos voksne. Vevet er metabolsk aktivt, og mengden er inverst proporsjonalt med kroppsmasseindeks og andre markører for metabolsk syndrom. Funnene kan kanskje benyttes i utviklingen av medikamentelle behandlingsformer for overvekt.

\section{Tidkrevende å lære laparoskopisk kirurgi}

Det er vanskeligere å lære metoder for laparoskopisk kirurgi sammenliknet med tradisjonelle metoder ved prostatakreft, viser en ny studie (Lancet Oncol 2009; 10: 475-80). Kirurger som allerede hadde erfaring med tradisjonell prostatakirurgi, fant det spesielt vanskelig å lære laparoskopimetoder. Pasienter hadde mindre risiko for tilbakefall dersom de ble behandlet av de mest erfarne kirurgene. 